\title{
Two RFLPs at the human renin (ren) gene locus
}

Philippe M.Frossard, Patricia A.Gonzalez, Lawrence C.Fritz, Phyllis A.Ponte, John C.Fiddes and Steven A.Atlas ${ }^{1}$

California Biotechnology Inc., 2450 Bayshore Frontage Road, Mountain View, CA 94043 and ${ }^{1}$ Cardiovascular Research Unit, New York Hospital, Cornell Medical School, 525 E. 68th Street, New York, NY 10021, USA

SOURCE/DESCRIPTION: $1.5 \mathrm{~kb}$ full length human renin cDNA isolated from a kidney cDNA library and subcloned into puC 9 (1).

POLYMORPHISM: Bgl I detects two allelic fragments of $5.0 \mathrm{~kb}$ and $9.0 \mathrm{~kb}$. Hind III detects a two-allele polymorphism with

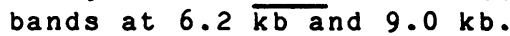

FREQUENCY: Studied in 80 unrelated North American Caucasians:

Bgl I $9.0 \mathrm{~kb}$ allele: $0.61,5.0 \mathrm{~kb}$ allele: 0.39

Hind III $9.0 \mathrm{~kb}$ allele: $0.66,6.2 \mathrm{~kb}$ allele: 0.34

NOT POLYMORPHIC FOR: Apa I, Ava I, Ava II, Bam HI, Dra I, Eco RI, Eco RV, Hinc II, Mbo I, Msp I, Nci I, Pst I, Pvu II, sst $I, \underline{x b a} I$ and $\overline{X m n} I$.

CHROMOSOMAL LOCALISATION: Human renin gene assigned to chromosome 1 by filter hybridisation of human-rodent somatic cell hybrids (2).

MENDELIAN INHERITANCE: Co-dominant segregation observed in 3 families ( 18 individuals) for Bgl I and 2 families ( 12 individuals) for Hind III.

PROBE AVAILABILITY: Requests for probe to L.C.F. at the above address.

OTHER COMMENTS: Low background under usual stringency conditions.

REFERENCE: 1. Fritz, L.C. et al., PNAS (in press) (1986); 2. Naylor, S.L. et al., Cytogen. Cell Genet. 37 (1984) 549 . ACKNOWLEDGEMENTS: This work was supported by Biotechnology Research Partners, Ltd. and the NIH grant IR43H34915-01. 